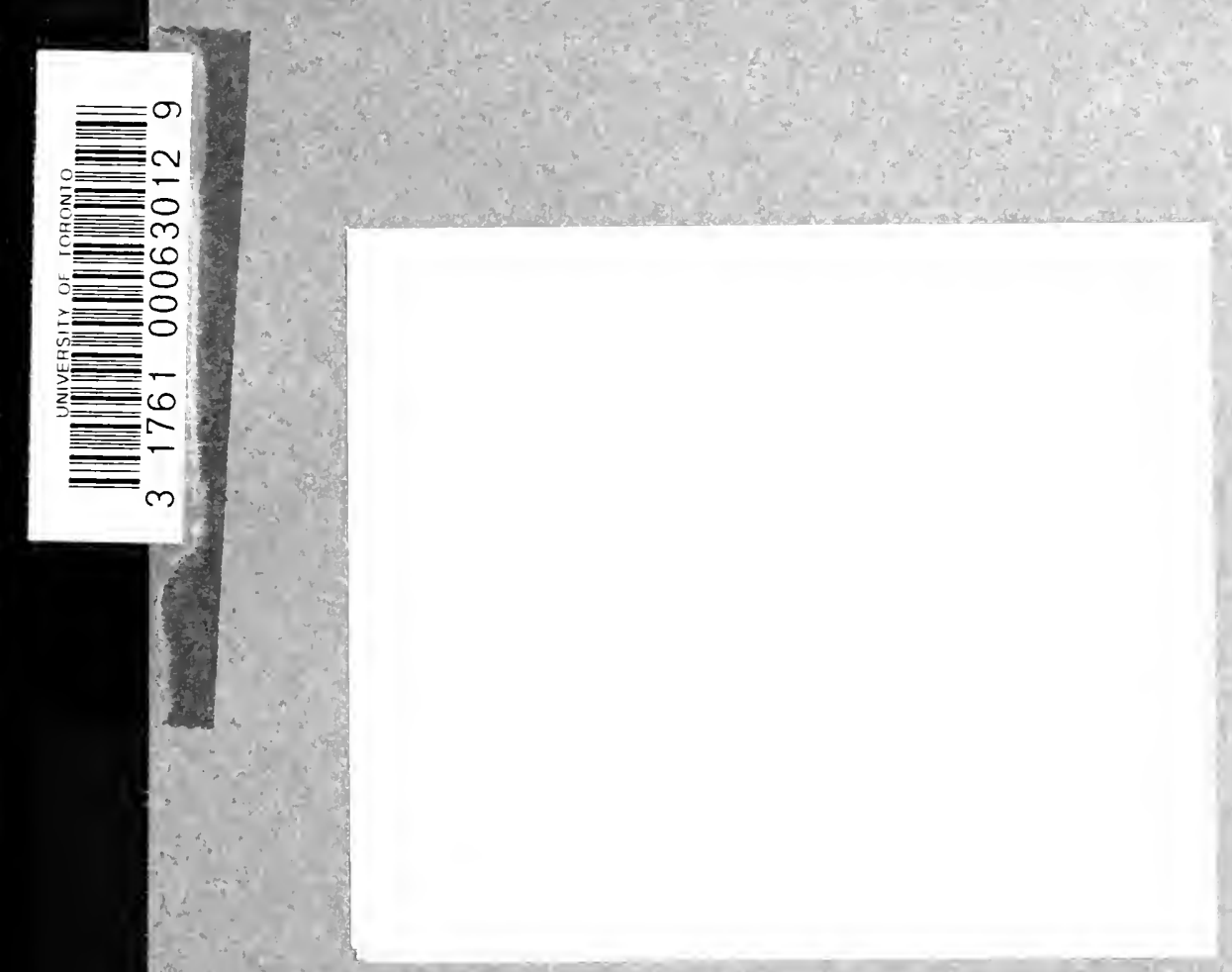




\title{
METAPHYSICAL PRESUPPOSITIONS OF RITSCHL
}

\author{
A DISSERTATION \\ SUBMITTED TO THE FACULTY OF THE DIVINITY SCHOOL \\ IN CANDIDACY FOR THE DEGREE OF \\ DOCTOR OF PHILOSOPHY \\ (DEPARTMENT OF SYSTEMATIC THEOLOgY)
}

W. C. KEIRS'TEAD

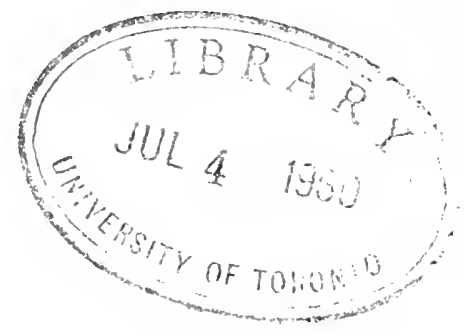

CHICAGO

1905 
1

\section{Digitized by the Internet Archive in 2007 with funding from Microsoft, Corporation}




\title{
Tbe aniversity of Cbicago
}

FOUNDED BY JOHN D. ROCKEFELLER

\section{METAPHYSICAL PRESUPPOSITIONS OF RITSCHL}

\author{
A DISSERTATION \\ SUBMITTED TO THE FACULTY OF THE DIVINITY SCHOOL \\ IN CANDIDACY FOR THE DEGREE OF \\ DOCTOR OF PHILOSOPHY \\ (DEPARTMENT OF SYSTEMATIC THEOLOGY)
}

IV. C. KEIRS'TEAD

CHICAGO

I 905 

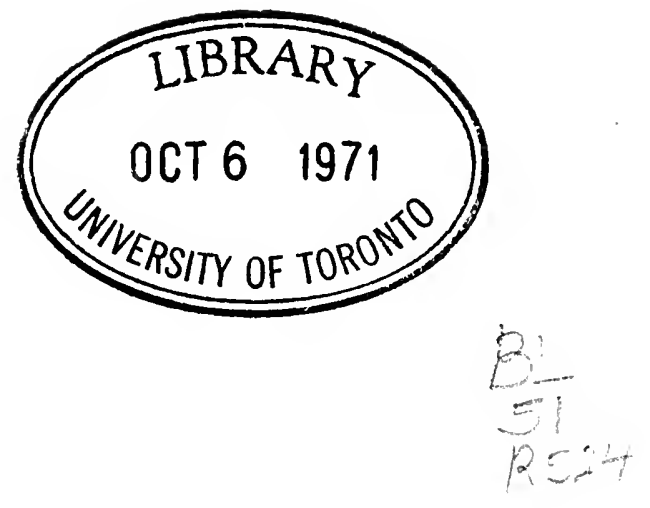


\section{METAPHYSICAL PRESUPPOSITIONS OF RITSCHL}

\section{W. C. KEIRSTEAD \\ Rockford, Ill. \\ I}

In his little book, Theologie und Metaphysik, ${ }^{2}$ Ritschl claims that every theologian is as a scientific man "under the duty or necessity to proceed according to a determined theory of knowledge of which he must be conscious and which he must be prepared to justify" (\$ 5, p. 66). As a scientific theologian, Ritschl claims ( $\$ 4$, p. 57$)$ that he follows a definite theory of knowledge, and that it is just because he rejects the traditional and Platonic theory of knowledge, which his opponents hold, that they are unable to understand him. This is the reason why he places value in things which they omit, and neglects matters which they regard as essential. "A Christianity which is expounded by a scholastic ontology and mystical psychology is unintelligible and neo-Platonic," ${ }^{2}$ while by his own method "a practical and intelligible Christianity is set forth." "The principles of logic, psychology, and epistemology constitute the ratio or intellectus necessary to comprehend revelation." Indeed, although Christianity as a religion is indifferent to any theory of knowledge, yet the latter is so important for theology that the whole strife between him and his opponents is, in Ritschl's opinion, a strife over a correct theory of knowledge.

Since Ritschl assumes such importance for a theory of knowledge, it is necessary to understand both his conception of epistemology in general and its function in theology. In order to define a theory of knowledge, we must understand his conception of metaphysics. "For a theory of knowledge here intended is identical with the

I Last edition published with Die christliche Volltkommenheit (Göttingen, 1902); referred to in this essay by the abbreviation $T M$.

${ }^{2}$ Ritschl, A Critical History of the Christian Doctrine of Justification and Reconciliation (English translation by H. R. Mackintosh), Vol. III, p. 23; referred to in this essay as $J R$. 
doctrine of the thing or things which forms the first part of metaphysics" (TM, p. 32). "Metaphysics deals with the universal ground of all being. It abstracts from the peculiar nature of natural and spiritual magnitudes in order to get the conception of a thing which is common to both" ( $J R$, p. I6). Metaphysical knowledge is therefore a priori knowledge. Metaphysics may be divided into two parts. The first part is ontology, or the doctrine of things. It presents

the forms arising in the intelligible spirit of man in which it proceeds in general to fix the objects of representation above the currents of sensation and perception. Thus metaphysical conceptions include and regulate all other acts of knowledge which involve the specific peculiarity of nature and spirit. They explain how it is that the human mind, having had experimentally perceptions of different kinds, differentiates them in consequence into natural things and spiritual beings. But it does not follow from the position of metaphysics as superordinate to experimental knowledge that metaphysical conceptions give us a more profound and valuable knowledge of spiritual existence than can be gained from psychology and ethics. Compared with psychology and ethics, metaphysics yields only elementary and merely formal knowledge (TM, p. $32 ; J R$, p. r6). A theory of things is employed formally in theology as settling the objects of knowledge, and defining the relations between the multiplicity of their qualities and the unity of their existence. The rules, which it is possible to set up here, form the conditions of experience by means of which the specific nature of things is to be recognized ( $J R$, p. 18).

In addition to ontology, metaphysics includes cosmology. In cosmology "the manifold of the perceived and presented things is ordered to the unity of a world, whether the world be conceived as limitless or as a whole" (TM, p. 33). This, too, is a priori knowledge, and deals with the pure forms rather than with the experimentally given. It presents those general forms of intuition, such as space and time, in which external nature is arranged. But cosmology takes no account of the difference between nature and spirit, and its knowledge is also elementary and superficial. In fact, it applies the results of ontology to the realm of nature; so that ontology is the most important part of metaphysics.

From this we see that for Ritschl a theory of knowledge is identified with ontology, and since this is the chief part of metaphysics, Ritschl virtually equates a theory of knowledge and metaphysics. For this reason Ritschl denies the charge that he rules metaphysics out of 
theology. "The question is," he says, "what metaphysics one will accept." He rules a false metaphysics out of theology, but he is enabled to do this by a true theory of knowledge, or because he recognizes the sphere and limitations of metaphysics.

Moreover, since for Ritschl a theory of knowledge is equated with ontology, the criticisms of Stählin ${ }^{3}$ and Pfenningsdorf, ${ }^{4}$ that Ritschl in his emphasis on a thcory of knowledge is opposed by Lotze, must, at least, be modified. Lotze does object to the method of beginning the study of metaphysics by a preliminary critique of reason. It is not by tracing the genesis of our notions that we decide concerning their meaning and value. "The psychological origin of knowledge, and the play of conditions which co-operate in producing it, is the most obscure of all questions." view of reality "the process of cognition is itself a part of existence," 6 and, indeed, a most important part. "The investigation into what our perceiving soul contributes to the excitations which move itthat is, a critique of reason-does not require to precede metaphysics, but is a part of it." But Lotze does lay emphasis on ontology, and this is what Ritschl defines as a theory of knowledge. It is true that Ritschl does not give a clear statement of Lotze's position, and that he is influenced by Kant; nevertheless, his theory of knowledge follows closely the ontology of Lotze. He lays more stress than Lotze upon the genesis of the concept, and does not always differentiate this from the question of the validity of the concept. But it is evidently not his purpose to make a preliminary study of the powers of the mind in order thereby to fix the limits of knowledge.

The same question arises again when one asks what is the character of metaphysical knowledge. At first sight one is inclined to say that Ritschl accepts the Kantian position. Ontology and cosmology are names for Kant's forms of perception and the categories of the understanding. "Metaphysics presents the forms arising in the spirit of man, in which it proceeds in general to fix the objects of representation above the flow of sensations and conceptions" (TM, p. 33). Meta-

3 Kant, Lotze and Ritschl (English translation).

4 Dogmatisches System von Lepsius und Ritschl.

5 Introduction to Metaphysics, Vol. I, §ix.

${ }^{6}$ Erdmann, History of Philosophy, Vol. III. 
physical knowledge is formal and a priori. It is worthless for theology. One is inclined to say that the problem of metaphysics is surrendered, and in place of it we have an analysis of the human mind. We discover the forms of perception and deduce the categories of the understanding. Knowledge, then, is limited to phenomena. An attempt to form a metaphysics results from the illegitimate use of the forms and ideals of the understanding and reason beyond the data of sense. Real knowledge is in the natural sciences. Theology is a special science, gets its material through historical revelation, and is limited to phenomena. There is much in Ritschl to suggest this interpretation, and he has been so understood; but a more careful study of him will prove that it is incorrect. For Ritschl says that metaphysics does give us real knowledge. It is superficial and elementary knowledge; it is not valuable knowledge; but it is knowledge of things. It tells us the nature of the ground of all being. And since it does give this universal ground of being, it does not take into consideration the difference between nature and spirit.

Metaphysical concepts are elementary knowledge in which one fixes the objects of knowledge as such, that is, as things in general, in their unity and further in their general relation to each other. For this reason spiritual magnitudes are only superficially and imperfectly known in metaphysics, and not in their characteristic reality $\left(T M\right.$, p. $\left.5^{6}\right)$.

And the doctrine of God affords a place where a metaphysical idea is presented directly as theological. "The remaining propositions of theology," says Ritschl (TM, p. 40), "are of such a specifically spiritual (geistiger) character that metaphysics comes into consideration only as the formal rule for the knowledge of religious magnitudes or relations." Then, too, the so-called proofs for the existence of God fail, because they cannot rise above the world-ground, they cannot prove the spirituality of God. All this seems to show that, while Ritschl's form of statement is Kantian, his position is rather that of Lotze. He has not in mind the difference between form and content which Kant makes so fundamental. He follows Lotze in that he begins with our notions of things, and accepts the conclusion of Lotze. Ontology with Ritschl, as with Lotze, gives elementary knowledge of things; it even leads to a unitary world-ground. Ritschl concedes thus much to metaphysics, and for this reason the 
doctrine of God is the only theological proposition which comes in contact with metaphysical knowledge. Ritschl,7 however, claims to limit his agreement with Lotze's metaphysics to ontology.

Lotze admits that metaphysics "will only be able to unfold ideal forms to which the relation between everything real must conform." In ontology "we seek a definition of thingness." "We deal with a discovery of the universal formal predicates which must appertain to all that (whatever else it may be) which is called thing, or which appears in actuality as a subject of relations." Lotze starts from the general notions of a thing, and seeks to purify these in such a way as to attain a consistent and contradictionless concept. As a result, he reaches certain universal and necessary forms or categories of thought. But Lotze would reject Kant's method of the deduction of the categories. The content of sensation is as subjective as the forms of thought, and the validity of knowledge has to be determined on other grounds than from the analysis of the process of cognition. Lotze simply defines thingness in such a way as to have a consistent conception, and, as Mertz says:

The assumption that these modified notions thus gained have an objective meaning, and that they somehow correspond to the real order of the existing world, which of course they can never actually describe, depends on the general confidence we have in our reasoning powers, and in the significance of the world in which we ourselves, with all the necessary courses of our thought, have a place assigned to them in harmony with the whole. ${ }^{\text {to }}$

If it be said that Lotze's method is an illegitimate abstraction of the universal element from its content in concrete experience, and the final positing of this as an absolute to account for experience, then this, if correct, is a criticism upon Lotze's ontology which Ritschl accepts, and possibly upon idealism in general.

Ritschl's critics point out that he cannot accept the ontology of Lotze, since the latter reaches a unitary spiritual world-ground in which things are conceived as spiritual entities, while Ritschl claims that metaphysics does not do justice to spiritual magnitudes, because

7 See Ecke, Theologische Schule Ritcshl's, p. 50.

8 Metaphysics, Vol. II, \& vi.

9 Outlines of Metaphysics, § I5.

to Mertz, Encyclopadia Britannica, art. "Lotze." 
it does not take into consideration the difference between nature and spirit. But there is no disagreement here; for Lotze says that ontology has not to deal with values.

Nature and spirit are two regions so different at first sight as to admit of no comparison, and demanding two separate modes of treatment, each devoted to the essential character by which the two regions are alike self-involved and separate from each other. But, on the other hand, they are destined to such constant action upon each other as parts of one universe that they constrain us at the same time to the quest for those universal forms of an order of things which they both have to satisfy alike in themselves and in their connection with each other. ${ }^{\text {II }}$

Metaphysics, Lotze tells us at the close of his ontology, "might accept a thoroughgoing determinism in which all that happens would be the inevitable and blindly necessitated result of all that has previously happened." 2 Such a view appears "incredible and preposterous" only "when estimated according to its significance and value." The world-substance for Lotze is by no means the God of religion. Mertz remarks that Lotze would probably claim that

the empty notion of an absolute can only become living and significant to us in the same degree as experience and thought have taught us to realize the seriousness of life, the significance of creation, the value of the beautiful and the good, and the supreme worth of personal holiness. To endow the universal substance with moral attributes, to maintain it is more than the metaphysical ground of anything, to say it is the perfect realization of the holy, beautiful, and good can only have a meaning for him who feels within himself what real, not imaginary, values are clothed in these expressions. ${ }^{13}$

Schiller, ${ }^{14}$ in his criticism of Lotze's monism, says that Lotze never bridges the chasm between his metaphysical world-ground and the God of religion. In his religious philosophy Lotze presupposses only the religious conceptions as historically given problems of religious philosophy. It is not possible from his world-unity to extract any of the divine attributes.

Ritschl claims to accept Lotze's ontology, and his own brief statements concerning the nature of metaphysics agree with this claim. Metaphysical knowledge then gives us an elementary knowledge of things, but it does not deal with values, and so makes no difference between nature and spirit.

II Metaphysics, Vol. I, \& xiii.

12 Outlines of Metaphysics, $\$ 75$.

I3 Encyclopadia Britannica.

${ }^{14}$ Philosophical Review, Vol. V, pp. 225-45. 
If, then, metaphysics gives only elementary knowledge, it is not difficult to define its relation to theology. Metaphysics does not even give valuable knowledge of things. If we want that, we turn to the natural sciences. It is even more impotent in the realm of spirit. Metaphysics deals only with that which is common to nature and spirit alike. Religious knowledge depends entirely upon that which is peculiar to spirit alone. "The religious world-view rests entirely on the fact that the spirit differentiates itself in worth from the phenomena surrounding it and the effects of nature forcing themselves upon it" (TM, p. 33). Metaphysical knowledge is worthless for theology. Why, then, is a theory of knowledge so valuable for the theologian? Because it has a formal, regulative, and critical function in theology. If one has the correct conception of metaphysics, he will not seek in its knowledge and by its methods to attain the content of theology. All the so-called proofs for the existence of God, and all speculations concerning the pre-existence of Christ and original sin, result from the use of a false theory of knowledge. These proofs can never rise above the world-unity; they cannot give the personality of God. "The use of metaphysics must be forbidden in theology, if the latter's proper and positive character is to be maintained" $(J R$, p. I 7). A theory of knowledge can be used critically by a theologian as a weapon agairist speculative metaphysics and natural theology. The content of theology is absolutely excluded from the elementary and general knowledge of metaphysics.

But Ritschl's opponents would understand by metaphysics, to use his own words, "not that elementary knowledge of things in general which ignores their division into nature and spirit, but such a universal theory as shall be at once elementary and the final and exhaustive science of all particular orders of existence" ( $J R$, p. I6). This is why they mingle metaphysical knowledge with revelation. Thus an alien content is mingled with the knowledge of the historical revelation because of a false concept of metaphysics. But this in turn is the result of the overestimation of the speculative method. This method fails to realize that the concepts and laws of human thought are methodological, and give but a partial and imperfect knowledge of reality. It is not for us in our thinking to follow the very laws that the Creator himself must have employed in creation. 
A theory of knowledge then corrects this presumptive method. We cannot deduce all from an idea. We must know objects in their relation to us. In so far as the finiteness of knowledge makes objects phenomenal, then all objects are phenomena.

If God belongs as an object of knowledge to scientific theology, then there is no satisfying ground for any claim that one could know something of God in himself, which would be unknown to us apart from the revelation which is somehow created by him, but felt and perceived by us (TM, P. 59).

We know things in their relation to ourselves. For this reason we cannot know a passive soul behind and apart from all conscious action; we cannot speculate about the eternal pre-existent union of Christ with God, or the metaphysical attributes of God. The false method did not take into consideration the relation of the object to consciousness. "They want the objective bearing of doctrine and not the interpretation of them as reflected in the subject. But we observe and explain even the objects of sense-perception, not as they are in themselves, but as we perceive them" ( $J R$, p. 34).

Wenley's criticism of Ritschl ${ }^{15}$ is not just; for Ritschl never claims with Kant that in knowledge acquired through the senses we know phenomena, while in the moral and religious realm we deal with things in themselves. For Kant the practical reason does not give knowledge at all. We postulate God, freedom, and immortality, but we have no knowledge of them. We know that they are, but not what they are. It is because we have no knowledge of them that they are not phenomena. For Ritschl real knowledge of God is given in his historical revelation; but this, like all our knowledge, is the knowledge of a finite being, and so is partial and imperfect. Ecke's statement is more just to Ritschl when he affirms that the latter makes no difference between the objects of natural and spiritual knowledge in the matter of their knowableness; and this, he thinks, shows clearly that both the existence and the possibility of the knowledge of objects was for Ritschl an undoubted fact. ${ }^{16}$ Wegener, who charged Ritschl with subjectivity, says that Ritschl makes no difference between the supersensual objects and those of sense-perception. Both appear under the same limitations. ${ }^{77}$

Is Contemporary Theology and Theism, pp. 82-124.

16 Theologische Schule Ritschl's, p. 48.

17 Jahrbücher für protestantische Theologie, 1884. 
Ritschl then identifies a theory of knowledge with ontology. $\mathrm{He}$ admits that ontology gives a general and elementary knowledge of things. But this knowledge has no place in theology, for the latter is confined to the value of the spirit. Then again the method of metaphysics is a priori. But this speculative method cannot give us valuable knowledge. The method of theology must be inductive, not deductive; historical, not speculative; scientific, and not metaphysical.

\section{II}

Ritschl finds three theories of knowledge prevalent in his age. The one he accepts is a mean between the other two, and avoids the mistake of each. The first view claims to know "things-in-themselves." It ignores the limitations of human knowledge. The other is agnostic and denies all knowledge of reality. The one which he accepts affirms, he thinks, a partial, but real, knowledge of reality. "We know the thing in its appearance."

The first theory of knowledge is due to the stimulus received from Plato, and found a home in the realm of scholasticism. "According to this view, the thing works upon us by means of its mutable qualities, arousing our sensations and ideas; but it really is at rest behind the qualities as a permanent self-equivalent unity of attributes" ( $J R$, pp. I8, 19, 20). This conception of a thing is carried over into scholastic psychology. "It is assumed that behind specific activities of feeling, willing, and thinking, the soul remains at rest in self-equivalence as the unity of its diverse powers." And it is with this metaphysical passive soul that a metaphysical passive Deity enters into union.

Ritschl points out the contradictions involved in this view: The thing or soul is passive and at rest, and yet it must be active, since it is the cause of qualities. (2) A temporal and spatial separation is made between the thing or soul at rest and the qualities which appear. Thus the thing is so severed from its qualities and the soul from its functions that it is not possible to view them as cause and effect. (3) Such a passive soul or thing would be absolutely unknowable for us.

In his Theologie und Metaphysik ( $\$ 4$, pp. 59 ff.) Ritschl seeks to account for the origin of this theory. He says, in substance, that 
the guarantee for the reality of the thing is to be found in the sensa tions which it excites in us. Yet sensations often deceive us. In any interpretation of sensation, at least, there may be illusions. We seek to avoid this by subsequent and more careful observation. Then the common view makes the mistake of supposing that by repeated presentations and more exact observation we can know things as they are in themselves. We have the image as first perceived, in which there is illusion, and then we have the perception as purified by renewed presentation and observation; and the common view regards the first image as a thing in relation to us, and the latter as the thing-in-itself; i. e., the thing as it is apart from relation to any consciousness. It is assumed that all illusion arises from the relation of things to us, and that, when we know things in themselves, there can be no illusion. But if there is always illusion (Schein) in the relation of things to us, then there is no possible way to detect and measure the illusion. For we find out illusion by comparing our conceptions with those of others, or by repeated observations. But we can never contrast the object as related to us with the object apart from all relations to our consciousness. "We are not able to separate from the relation of things in general the necessary and unfailing relations to us as the subjects of sensations, perceptions, and ideas." An object apart from all relations to us would be absolutely unknowable. It is non-existent for us. We, then, know things in their relation to us and to one another. And the fact that we so know them is no discredit to our knowledge. But we know objects as related to a finite consciousness: our knowledge is limited. The vulgar view that we know things-in-themselves is incorrect. It is incorrect because things apart from all relation to us are absolutely unknowable for us, and it is mere dogmatic assumption to say that they exist at all. Then it is incorrect to say that objects are related to us as they are to a perfect consciousness. We know things as they are for us.

The second mistake of the vulgar view of things arises from taking "the mere stationary memory-image of repeated intuitions and effects by which our sensations and perceptions have been stimulated all along within one definite place" for the thing-in-itself. This, however, comes about as follows: When we have repeated 
perceptions of the same thing under different conditions, there are certain qualities which are present in every presentation. These qualities get a certain stability and clearness, and by a process of involuntary abstraction we form them into a mental image of the thing. Moreover, we have a feeling of the value of this image, inasmuch as it guides, shortens, and makes easier renewed observation. We were originally assured of the reality of an object by its changing affection, by the sensations which it excites in us. And the memoryimage, because of the feeling of its value, is put on a par with the experience which originally guaranteed the reality of the thing. Because of the permanency and clearness of the memory-image in comparison with immediate experience, the mistake is easily made of ascribing to it the reality. The memory-image becomes the thing in itself, and is placed in a plane immediately behind the appearing thing. It is made the real cause of the sensations. There thus arises the contradiction already referred to. This is the psychological explanation of the scholastic thing-in-itself. The claim to know things-in-themselves turns out to be a deception of the memoryimage.

This is probably the psychological explanation of Plato's doctrine of ideas. Plato universalizes memory-images. For Plato's idea is but the class-concept which is formed by abstracting the common qualities of the individuals of a species; then Plato ascribed true reality to this concept. The things of sense-perception are supposed to exist and to be real in so far as they participate in the idea. The individual things are, as it were, shadowy images of the idea. These ideas exist in an intelligible world, and can be known by thought alone. Plato tries to think things-in-themselves, apart from their individual appearances to us; yet at the same time he has to make some sort of causal connection between the two. The very opposite of Plato is the truth. It is not the class-concept, but the individual, which is real. The more universal the concept, the paler, more fluctuating, and more undetermined it is; and when it is purified from these defects and is brought out in clear outline, it is the concept of an individual thing.

Frank is guilty of some such fallacy when he talks of the absolute. There is no such thing as substance in general. Frank's absolute is 
an abstraction; Lotze would call it "pure being." Since you cannot get a substance behind matter, Frank's concept of the absolute is materialistic. What Frank gives us, says Ritschl, as the absolute or thing-in-itself, is really an imperfect concept of a thing. This is Hegel's criticism of Kant's things-in-themselves. The absolute, Ritschl affirms, is the unrelated. Strictly speaking, this has no meaning. For if we speak of an object as absolutely unrelated, both to other objects and to our sense and intelligence, we are talking nonsense; for such an object is inaccessible to us. But Frank does not do this. He takes an imperfect concept of a thing-a concept that is stripped of all special qualities, of all its relations to other things and to our sense-perception; and he has left an abstraction, a purely formal concept, Kant's unity of apperception; and, of course, such an abstraction cannot give us real knowledge of reality. Yet this is the deception which Frank practices upon himself when he talks of his absolute. It is akin to the scholastic mistake of hypostasizing the memory-image. For a memory-image is virtually identified with a formal concept, since each has lost the special qualities of a concrete thing.

The whole process of thinking "pure being" or "things-inthemselves," meaning by that the unrelated, and then somehow attaching qualities to them in an accidental manner, is unclear and contradictory. The individual apple which we eat is the real apple, and the man in the direction of his will and in the harmony of his feeling of self, whom we learn to know, is he himself. Behind this we do not have to bring into consideration a more characteristic or real being of man to understand him. And the real God is the one who has revealed himself to us in historical revelation, and not the undifferentiated, undetermined, and limitless being which is attained by metaphysical speculation.

The second form of the theory of knowledge we owe to Kant. He limits the knowledge of the understanding to the world of phenomena, but declares unknowable the thing or things-in-themselves, though their interdependent changes are the ground of the changes in the world of phenomena. The latter part of the statement contains a true criticism of the scholastic interpretation of a "thing." The first part, however, is too near the scholastic theory to avoid its errors. For a world of phenomena can be posited as the object of knowledge only if we suppose that something real-to wit, the thing-appears to us or is the 
cause of our sensations and perceptions. Otherwise the phenomenon can only be treated as illusion. Thus by his use of the conception of phenomenon Kant contradicts his own principle that real things are unknowable $(J R, \mathrm{p} . \mathrm{Ig})$.

Ritschl's criticism of Kant is that he virtually accepts the scholastic conception and valuation of the thing-in-itself. He shows very correctly that the thing-in-itself is so separated from its appearances that a knowledge of it is impossible. Kant thus exposes the fallacy of the scholastic knowledge of the thing-in-itself. But he is to be censured in that this very fact did not lead him to give up such a conception of things. It is because he himself retains a scholastic conception that he denies a knowledge of reality; but in order to save knowledge from being mere illusion, he implies that appearance is an appearance of reality.

This leads Ritschl ( $J R$, pp. I9, 20) to state his own position, which is that of Lotze, and it involves such a conception of things-in-themselves, or of things, that we may have a real, though partial, knowledge of them. Ritschl rejects the scholastic conception, which defines a thing as the unrelated. The opposite is true. Things are in relation, and appearance is the knowledge of reality. "In the phenomena, which in a definite space exhibit changes to a limited extent and in a definite order, we cognize the thing as the cause of its qualities acting upon us, as the end which they serve as means, and as the law of their constant change." In his Theologie und Metaphysik ( $\$ 4$, pp. 63 f.), after showing the psychological origin of the conception of a thing, like Lotze, he starts from the ordinary conception of a thing to get a clear and consistent conception.

In the elementary stage of the formation of the conception of a thing there is no need [such as the scholastic view necessarily implies] to put in two planes, side by side, the thing, and its attributes which are felt and perceived by us at the same time, and to put the one behind the other, and to assert the possibility of the knowledge of the thing behind its attributes or before the recognition of them. Nor is there need of this, when the conception of a thing is enriched, when the marks are understood as manifest effects of a cause and as means to an end, when one recognizes the marks as changing in definite limits, and the whole as effective in the regular change of its attributes; when, finally, one supposes a law in the perceived history of a thing. [Rather] the thing is caused in its effects and purpose in the ordered series in its appearing changes.

These two passages contain the clear statements of Ritschl concerning his conception of the thing, and show his acceptance of the 
ontology of Lotze. According to the statements here, a thing is causality. It is operative and dynamic. It is activity. But it is not mere becoming. It is activity or change within certain limits and according to its own definite law. A thing has the purposive causality of a self.

Ritschl's statements are so brief that they cannot be understood except in the light of Lotze's fuller exposition. He accepts Lotze's idea of cause: causality is efficient. He accepts again Lotze's idea of change. "The phenomena of a thing exhibit changes in a definite sphere and to a limited extent." 8 Lotze tells us that "phenomena neither persist without change, nor change without a principle of change." But change with him indicates transformations or movements of the thing "within a limited sphere of quality." "The essence or substance of a thing is that which admits of change," but in change "the thing never passes over from one sphere to another."

When Ritschl defines the thing as the "law of the constant change of the qualities," or supposes "a law in the perceived history of the thing," he is giving an abbreviated statement of Lotze's position. For Lotze declares "that the essence of a thing cannot be expressed in a quality, but only in the logical form of a conception, which expresses the permanently uniform observance of law in the succession of various states or the combination of various predicates." 9 A thing for Lotze is known in its behavior. The complete conception of a thing includes its past and future history.

Even the actual present condition of a thing would not admit of exhaustive analysis without thinking of the mutual connection of the manifold phenomena which it exhibits as already ordered, according to the same law which would appear still more plainly upon a consideration of the various states past and to be expected of the thing.

This concept of a thing as the law of its changes serves to bring out the idea of unity in difference, and yet Lotze confesses that it is a very imperfect concept of a thing. For a thing is always more than a concept or idea. We must remember, too, the methodological character of our concepts. Then the term "law," as used above, needs to be defined. By the use of the term he does not mean a general law, but "an instance of its application." Then, too, law may be

I8 Metaphysics, Vol. I, chap. 2. 19 Ibid., chap. 3 . 
individual, and this is meant here. We may define the thing as "the realized individual law of its behavior." Yet this statement is not exact, since the law is not realized, but has always been real.

It is not a law which, though real as law, had still to wait to be followed, but one followed eternally, and so followed that the law, with the following of it, was not a mere fact or event that takes place, but a self-completing activity. And this activity we look upon, not in the nature of a behavior separable from the essence which so behaves, but as forming the essence itself-the essence not being a dead point behind the activity, but identical with it. But, however fain we might be to speak of a real law or a living idea, in order the better to express our thought, language would always compel us to put two words together on which the ordinary course of thinking has stamped two incompatible and contradictory meanings.

One may, or may not, accept this idea of a thing, but Ritschl does accept it, and when his statement is viewed and interpreted in the light of Lotze's fuller exposition, many of the criticisms of his opponents lose their force.

When Ritschl ascribes purposive causality to things-when the thing is defined as "the end which the qualities serve as means"he means to accept Lotze's view that things possess a certain selfhood. "If there be things," Lotze says, "with the properties we demand of things, they must be more than things. Only by sharing this characteristic of spiritual nature can they fulfil the general requirements which must be fulfilled in order to constitute a thing." 20

Our ideas, feelings, and efforts appear to be in their nature the states of a being, of the necessary unity of which, as contrasted with them, we are immediately conscious . . . . for these inner events appear to us as states only through the marvelous nature of mind, which can compare every idea, every feeling, every passion, with others; and, just because of this relating activity with reference to them all, knows itself as a permanent subject from which under various conditions they result. ${ }^{2 \text { I }}$

The self, then, is for Lotze the best example of a thing, and it is not in thought merely, but by our whole experience, that we are able to know ourselves, and what we mean by a thing. In the passages already quoted we see that for Lotze there is not some substance behind the thing or soul to which the qualities adhere. It is not a substance which lies behind things and gives them reality, but 
"reality is that ideal content which, by means of what it is, is capable of producing the appearance of a substance lying within it, to which it belongs as predicate." 22

We have seen that Ritschl accepts Lotze's definition of a thing. We have now to point out that certain passages indicate that, like Lotze, he held that things are in constant interaction. Lotze affirms that things are in interaction, and that the nature of the interaction is determined by the natures of the interacting things and by the relations existing between them. A certain state is not carried over from one body into another. ${ }^{23}$ But the effect in a body $\mathrm{A}$ is determined when we consider both the nature of $\mathrm{A}$ and of $\mathrm{B}$, the interacting things, and the relations $\mathrm{C}$ under which they interact. Further, the relation between subject and object comes under the general relation of the interaction of things. When subject and object interact, states are produced in the former. "Our ideas are excited in the first instance by means of external impulse." For this reason, an idea is not a mere copy of something. Since it comes under the general law of interaction, the nature of both subject and object, and the relation existing between them, co-operate in the determination of the idea. For Lotze the soul is active, and the sensation is not a passive content given, but the reaction of the soul upon the object which stimulates it.

Ritschl accepts this view ( $J R$, p. I8):

In the theory of things, it is taken for granted that the self is not of itself the cause of sensations, perceptions, etc., but that these peculiar activities of the soul are stimulated by its coexistence with things of which the human body is one (TM, p. 44).

The soul affirms itself as "cause of its changing sensations under the stimulus of the appearance of the thing." He speaks (TM, p. 64) of a "series of sensations excited by the thing."

For all causes which affect the soul work upon it as stimuli of the special activity with which it is endowed. The relation of the soul to all the causes which work upon it is not one of simple passivity; all actions upon it, rather, it takes up in its sensations, as a reaction in which it manifests itself as an independent cause (JR, P. 2I).

If sensations and perceptions are states in a self or thing as a result of its interaction with others, then knowledge is subjective, 
though it may have a transubjective reference. This is what Ritschl seems to hold. He gives the following as a psychological genesis of the concept of a thing:

The presentation (Vorstellung) of a thing arises out of the different sensations which, in a definite order, fasten themselves to something that perception fixes in a limited space. We posit the apple as a round, red, sweet thing, since the sensations of touch, sight, and taste bunch themselves in the place in which the corresponding relations of form, color, and taste are perceived. These same relations which by repeated perceptions meet in a common spot we unite in the idea of a thing, which exists in its relations, which we know only in these relations and designate by means of them. The relation of the marks in question, thus fixed by our sensations, to the thing which we express in the "judgment," "This thing is round, red, and sweet," signifies that we know the subject of this proposition solely in the predicate. Could we leave them out of view, or forget them, the thing which we had come to know in and by these marks would cease to be a matter of knowledge (TM, p. $\left.6_{3}\right)$.

The impression that the perceived thing in the change of its marks is one, arises from the continuity of the feeling of self in the succession of sensations excited by the thing. Further, the apprehension of the thing as cause and as its own end arises from the certainty that I am cause and that I an end in the activities due to me. . . . . The appearances which are perceived in a limited space in the same position or series, and their changes in a definite limit and order, are combined by our faculty of representation to the unity of a thing, after the analogy of the cognizing soul which, in the change of its corresponding sensations, feels and remembers itself as permanent unity ( $T M$, p. 44$)$.

In these passages Ritschl explains how we form the concept of the thing. He reminds us of Kant. And if these passages, together with the definition of metaphysics as presenting the categories of the mind (which was discussed in the previous section), were taken apart from his ontological position, we would pronounce Ritschl Kantian. We seem to have here Kant's logical or psychological division of form and content. We have the faculty of representation uniting the sensations into a phenomenon-thing. The thing, apart from this content, is a pure formal concept. Kant says: "The unity necessitated by the object cannot be anything but the formal unity of our consciousness, in the synthesis of the manifold in our representations." ${ }_{4}$ Kant tells us again: "Phenomena are nothing but sensuous representations, which therefore by themselves must not be taken for objects outside the faculty of representation." 25 
But is it possible for Ritschl here to be in agreement with his ontological position and with the general position of Lotze? That he thought so is plain from his appeal to Lotze in the very passage ( $T M$, p. 44) which sounds most like Kant, and in the other passage (pp. 63, 64) he passes at once from the genesis of the concept to its validity. Further, in these very passages the excitation of sensations is caused by the thing. In the matters here discussed the position of Lotze does not differ materially from that of Kant. For Kant the world of nature is the product of consciousness. It is constructed by the understanding. Phenomena, then, are in consciousness. While Kant's general thought is that consciousness embraces both subject and object, yet sometimes he would seem to imply that the world of objects is the mental construction of the individual conscious self. For Kant, then, we know phenomena. But now Lotze finds in this statement, that we know phenomena, ${ }^{26}$ a prejudice. What Kant calls phenomenon, the mental construction, it would seem that Lotze would call knowledge. Kant's phenomena are not realities, because they are a knowledge of reality, and knowledge is subjective. Knowledge is knowledge for someone just as truly as it is knowledge of something. Sensations, perceptions, and conceptions are elements of knowledge, and are the possession of an individual consciousness. Lotze says, in the passage to which Ritschl appeals:

We admit, therefore, the complete subjectivity of our knowledge with the less ambiguity because we see clearly, moreover, that it is unavoidable, and that although we may forego the claim to all knowledge whatever, we can put no other knowledge in the place of that on which doubt is thrown that would not be open to the same reproach. . . . But this universal character of subjectivity as belonging to all knowledge can settle nothing as to its truth or untruth. And it is a fallacy, on account of the subjectivity of all the elements out of which it has been formed, to deny its truth, and to pronounce the outer world to be merely a creation of our imagination. For the state of things could be no other, were the things without us or not. Our knowledge in the one case, our impressions in the other, cuuld alike consist only in states or activities of our own being-in what we call impressions made on our nature, supposing these to be things, but on no supposition on anything other than a subjective property of ours. ${ }^{27}$

The demonstration of a thoroughgoing subjectivity of all the elements of our cognition, sensations, pure intuitions, and pure notions of the understanding is 
in no respect decisive against the assumption of the existence of a world of things outside of ourselves. For it is clear that this subjectivity of cognition must in any case be true, whether things do or do not exist. For, even if things exist, still our cognition of them cannot consist in their actually finding an entrance into us, but only in their exercising an action upon us. But the products of this action, as affections of our being, can receive their form from our nature alone. And it is easy to persuade ourselves that, even in case things do actually exist, all parts of our cognition will have the very same subjectivity as that from which it might be hastily concluded that things do not exist. ${ }^{28}$

In his Logic, ${ }^{29}$ Lotze points out that an intelligence can never be the thing-in-itself, but can only "have an aggregate of ideas about the thing. He who demands a knowledge which shall be more than a connected and consistent system of ideas about the thing-a knowledge that should exhaust the thing-itself-is no longer asking for knowledge at all, but for something entirely unintelligible."

What, then, Kant calls phenomena, Lotze would apparently call knowledge. Sensations, percepts, concepts, unite to form knowledge, but not things. They are processes in the individual consciousness. But things exist for Lotze whether we know them or not. When you ask after the psychological genesis of knowledge-that is, after the relation of sense to understanding-Lotze's position is similar to that of Kant. He advances somewhat upon the psychology of Kant, but his general position is the same. There are with Lotze certain a priori elements in knowledge, there are logical acts which have formal and not real significance. He says:

We cannot assent to the distinction between the matter and form of knowledge as drawn by Kant. The idea is, indeed, perfectly just, but he formulates it inaccurately when he ascribes the entire content to experience, and the form alone to the innate activity of the mind. Kant was well aware of the fact that even the simplest sensations which in the strictest sense furnish the original content of all our perception do not come to us ready made from without, but, on the contrary (if we are to hold to the concept of an external world), can only be considered as reactions of our own nature of combined sense and intellect in response to the stimuli coming from that world. ${ }^{\circ}$

It is not, then, for Lotze that the content of sensation is furnished by an unknowable, and that the mind subsumes this under its own forms; but rather that the soul, stimulated by its interaction with 
things, reacts in the form of sensations, feelings, and ideas. The concept of a thing is formed from its continued activity. Now, it is a "sensation which is our warrant for the presence of real being. .... There is this reality of content, which in the last resort is given only in sensuous perception." ${ }_{31}$ "Sensation is the only warrant for the certainty that something is." If now you abstract from your concept of the thing all the qualities, you have left an abstract form which cannot convey knowledge of any particular thing.

Ritschl, then, is in accord with Lotze when he describes the genesis of a concept as a subjective process; when he further says that, apart from its qualities, a thing is a purely formal concept; and when he affirms that "the sensations which come to us through the senses are the first and last guarantee that the things, which we perceive in the sensations which they excite, exist or are real" (TM, pp. $\left.44,5^{8}\right)$. He is in accord with him when he affirms that the unity of the concept arises out of the continuity of the feeling of self, and when he ascribes cause to the thing after the analogy of the soul. Lotze affirms that "what we take to be the perception of a thing is never more than a plurality of contemporary sensations held together by nothing but the identity of the place at which they are presented to us, and by the unity of our consciousness which binds them together as intuitions." ${ }^{32}$ But, says Lotze, the natural theory of the world never believes that it finds the essence of the thing in these qualities, and he seeks for a more adequate conception of the thing. Ritschl follows him when he says that the subject is known in its predicates, and uses for illustration the very sentence of Lotze: "The thing is round, red, and sweet." But he passes at once from what he calls an elementary concept of a thing to a more adequate one, that is, to Lotze's definition of a thing.

But how can we pass from the genesis of the concept to its validity? How go from the subjectivity of knowledge to the transubjective reality of the thing? Ritschl does this several times, but he never tells us how. Let us turn to Lotze. It is, indeed, a difficult question for him to answer. He gives us an antithesis of thought and things, but just how thought assures us of things which are not thoughts is a difficult problem. It seems to come down to the fact of intuition, 
of immediate conviction, to feeling, to the sensation itself. It is a deep conviction which we must accept as true. "Fichte did not draw the only logical inference that could be drawn, namely, solipsism. And if you admit the existence of others, then why not of real things." Bowne, a disciple of Lotze, calls things "projected conceptions." "We do not know," he affirms, "how our thoughts, which arise and exist only in our consciousness, should yet grasp realities independent of our consciousness; but we are compelled to admit the fact, and if in one case, then why not in others." Lotze acknowledges that there is not the same necessity for this in the case of things that there is in that of persons. For a Universal Being could act upon us in such a way as to produce a uniform impression of things, and satisfy all our intellectual demands. A subjective idealism is then a possibility. But, in general, Lotze assumes the existence of things as a fact of which we are immediately conscious. And his explanation of this would seem to be as follows: Things exist in interaction. Sensations, ideas and feelings are the states in a conscious being which arise through this interaction. They give us knowledge of reality. Appearance has both a subject to which it appears and an object which appears. Ideas are not things, they are not copies of things, but they are valid of things. Every sensation, feeling, or idea "is in itself a bit of information about reality;" 33 it is the very nature of knowledge that it gives us information of things beyond the immediate experience. The concept of a thing may arise in the child-mind after repeated experiences. And the concept conveys to the child information concerning its own cause. It is in this light that Ritschl is to be interpreted when he makes real things the cause of experience, and yet regards the concept of the thing as the product of experience.

The interpretation given above seems to be Lotze's thought. If so, then he teaches that we know reality. We have partial knowledge because we are finite, and stand, not in the center, but at the periphery of reality. We can outline reality; we can tell its formal character. Things are soul-like entities; but our knowledge is limited. For Lotze this is not valuable knowledge which leads us to see the formal nature of things; but the laws of science, and the values which ethics 
and religion express, constitute the really valuable knowledge and give content to the reality whose formal character ontology delineates. If we were to accept Lotze's Logic alone, we would be inclined to say that he limits knowledge to phenomena; but in that case he should not discuss the nature of things in themselves. Interpreters differ, and Lotze is so many-sided that it is difficult to understand him. Robins interprets him in accordance with the interpretation here given. Many of his students take the same general position. Ritschl seems to have interpreted him thus, and that is important for us. He considers him a mean between gnostic scholasticism and agnostic Kantianism.

In Ritschl's theory of knowledge he denies the scholastic conception of substance as the essence of things. He denies the separation they make between the thing and its qualities. He denies their claim to perfect knowledge, and finds in it a logical fallacy. They transform a logical concept into a metaphysical entity. They overemphasize the laws of thought, and make them constitutive of reality when they are only methodological. He rejects Kantianism. It is not true that we know only phenomena. This reduces knowledge to an illusion. He accepts Lotze's position, and interprets him to mean that we have a partial knowledge of reality. We know the formal nature of things by metaphysics. Their real nature is learned by experience, and induction is the method of procedure. We can never know things as a perfect intelligence knows them, but only as they are for us. Knowledge is subjective. It is the possession of an individual consciousness, but it has an objective reference.,

\section{III}

I. The Platonic theory of knowledge.-Wendland says ${ }^{34}$ that Ritschl does not know the difference between a memory-image and a concept. Neither does he appreciate the function of a concept. Our concepts are not merely a matter of preference, but we are led to form them by the nature of reality outside of us. When a class-concept is correctly formed, it is as sharply and clearly drawn as that of an individual thing. Ritschl virtually denies that careful thinking fol-

34 Albrecht Ritschl und seine Schüler, pp. 37-46. 
lowing perception can give us a better knowledge of objects than perception alone.

Lüdemann ${ }^{35}$ considers it is false to compare ideas as Plato used them with memory-images. Plato, moreover, held that the ideas were in relation to us, though not to our sense, yet to our thought; so they are not things-in-themselves. These ideas were not to account for the changeable, but the endurable in things. His ideas were concepts, and when Ritschl fails to find a definite and clear knowledge in them, it is because he confuses concepts with intuitions.

Esslinger ${ }^{3}$ judges from Ritschl's attacks upon class-concepts that he would forbid conceptional thinking, since he regards it as selfdeception to attain definite and clear knowledge by means of concepts. One, then, knows less about on object after reflection upon it, than before. Ritschl needs to be reminded that "percepts without concepts are blind." The idea of an apple is a definite and clear presentation.

These criticisms contain an element of truth. Ritschl does not discriminate between an image and a concept. The difference is entirely one of function. A concept is a rule for the construction of the object or class. The image may serve for the picture of the concept. One does not always fill out the picture fully. But the image is always particular. There is no image of a horse in general. The difference between the particular and the general is one of function.

Ritschl, in his brief statement of Plato's ideas, does not do justice to that philosopher. His ideas were universals. Lotze, in his Logic, ${ }^{37}$ recognizes the problem of Plato, and ascribes to his ideas the reality of eternal validity. He thinks this is what Plato himself meant to claim for them. But Ritschl does put his finger on the difficulty in Plato's thought, namely, the causal relation between pure eternal being and the changing individual things of sense-perceptions. Ritschl, moreover, is correct when he says that, because of the logical value of universals and concepts, they are often improperly valued and employed. They are given a metaphysical existence. The relation of substance and attribute is a logical one. We call that "attribute" or "quality" which we cannot think of without ascrib-

35 Protestantische Monatshefte, I 897 , pp. I89-205.

${ }^{36}$ Zur Erkenntnisstheorie Ritschl's.

37 Logic, $\$ \S 316-20$. 
ing it to something else, and we call that "substance" which we regard as the bearer of these qualities. A thing, then, is a substance in respect to something else. Substance and qualities are correlates. And the same thing may be a quality with respect to one thing, and yet be regarded as substance in respect to another. Now, in the case of a physical body there are certain qualities which, as Ritschl points out, are constant, e. g., extension and resistance; while there are others which change with every experience. We may regard the former as substance, since they represent the relatively common or constant element in our experience. We may call them the essential elements of the thing, and regard the other qualities as accidents. But when we regard them as forming a separate metaphysical entity, to which the other qualities are attached, we have, as Ritschl affirms, hypostasized a logical abstraction. These qualities of extension and resistance, as a separate metaphysical entity, have no more reality apart from the whole concrete experience than do the other qualities which change with every perception. The same may be said with regard to any state of self-consciousness. There are certain elements which are relatively constant. The impulsive element of will, or that which Kant designates the "I think," may be found in every state of consciousness. Every state of consciousness is impulsive, or it is owned. I cannot have a state of consciousness without thinking of it as mine, without referring it to the ego. Yet to make of this will-element present in every concrete state, or of this "I think," a separate and metaphysical entity which lies behind consciousness and is the cause of all its states-to find in it a metaphysical self-is to hypostasize a logical abstraction which can have no existence apart from the concrete whole from which it has been abstracted. ${ }^{38}$ In his doctrine of the memory-image Ritschl does point out how metaphysical entities are placed behind souls and things as substances or things-in-themselves which support the qualities and activities. In doing this he places himself in line with modern psychology and logical thought.

Ritschl does not stand for the particular against the universal, as Esslinger affirms, but for the individual as against either an abstract particular or an abstract universal. He does not say that repeated

${ }^{38}$ Cf. Frank Thilly. Philosophical Review, Vol. XI. 
observation and reflection will not give us a better knowledge of things-he tacitly assumes that they do; but he does say that these repeated observations and reflections simply relate the thing more completely to the self, and so the thing by them is not known apart from its relations to us. When Ritschl denies that a clear knowledge can be gained from the concept of an apple, his real point is one of method. It is not wise to begin with the concept of "apple," "soul," or "absolute," and from this concept seek to attain truth by means of speculative and logical thought. Here Ritschl has in mind Hegelianism, and is influenced by Lotze. The latter everywhere points out the danger in taking universals of thought for reality. He affirms, over against the constitutive nature of thought, its methodological character.

Every concept expresses only an aspect of a thing. There can be several equally right and fruitful concepts of the same thing. The concept manifests only a part of the nature of the thing. It beholds it from the periphery and not the center. All such concepts are liable to change and modification, and can gradually develop and express more and more the nature of a thing. ${ }^{39}$

But does not Ritschl lay too much stress upon the abstract character of thought? For him the process of attaining universals is a process of abstraction. The greater the extension, the less the intension. Lotze $4^{\circ}$ tells us that the universal has as many marks as a subsumed individual, but that the marks are general in the former, while in the latter they are definite. Yet even he admits that in the most general universal some marks would be reduced to zero. We may admit that all thought is an abstraction. But it is a necessary abstraction. It is so because the reality of immediate experience has gone from us, and we seek a method to bring us in contact with reality again. Thought is abstract because it is only a phase of experience; it is abstract as long as it is inadequate. But when we say that the forming of universals is an advance in abstraction, we are looking at but one phase in the process. We do abstract to attain a universal, but we attain the universal to apply it, and in that sense the process is toward concreteness. Let us take Ritschl's concept of

39 Robins, Lotze's Theory of Knowledge, chap. 2, p. 63; cf. also Lotze, Logic, $\S \S 345,3$ I6, I 38 ; Mikrokosmus, Vol. II, pp. 333 ff.

40 Logic, $\$ \$ 25-33$. 
an apple. We form the concept "apple" as the predicate of the judgment, "This is an apple." Now, if this is a live judgment, we know more about the subject, the "this," than we did before the judging process. It is not a pear, or some other fruit, but an apple. And we know more about the predicate, the "apple," since all apples are now related to this one particular species of fruit. Knowledge is relating, and every advance to universals means an increase in relations.

Ritschl is correct in his emphasis on the individual. The individual apple is the real apple. It is this I must take account of, if I would have the experience of eating an apple. This functional point of view would mean some change in Lotze's concept of a thing, though he approaches it when he defines a thing in terms of its behavior.

Ritschl's criticism of the scholastic conception of the soul has received severe criticism from the pen of Pfleiderer. ${ }^{4}$ The latter thinks that when Ritschl gives up the concept of a soul as a thing-initself, he takes the position of the Positivists. They explain

the unity of the self as appearance and only the manifoldness as the reality; but how this appearance could ever be brought about, how the actual consciousness of the identical ego, how the continuity of consciousness, how recollection from one day to another, is possible, if there are in us only changing functions, and not a permanent unity from which they proceed and into which they return, depositing there their results-this is and remains hereby wholly incomprehensible.

Ritcshl, moreover, contradicts himsclf when he maintains a selfsufficient moral character, for he assumes the "in itself of the soul." The doctrine of a soul which seeks to do without a soul will have difficulty in finding a place for immortality.

Garvey ${ }^{2}$ thinks that Ritschl's criticism of the scholastic separation of the soul from its activities is justified, and he agrees that that which is most valuable is our conscious activities, and not the subconscious. Yet Ritschl is incautious in his statement, and goes farther than present psychology demands. "Attributes and operations cannot be permanently construed, unless on the assumption of such a permanent unity which is manifest and active in, but is not

4I Ratschl'sche Theologie, pp. IO-I2.

$4^{2}$ The Ritschlian Theology, pp. I38-40. 
exhausted in, these attributes and operations." "There is a mental latency, an organic basis, which must be taken into account in a rational construction of personality, as well as the conscious functions and empirical variations." Yet the fact that Ritschl accepts Lotze's definition of a thing which is applicable to the self, as well as his treatment of the divine personality, shows, he thinks, that Ritschl never meant to deny the unity of consciousness.

Traub ${ }^{43}$ agrees with Ritschl. Pfleiderer identifies the scholastic concept of a soul-in-itself behind its conscious functions with the conception of the unity of consciousness, and the whole force of his criticism that Ritschl dissolves the soul into a multiplicity of its functions rests upon this mistaken identification. But the unity of the soul is not in a substance behind consciousness. The assumption of an individual soul-substance behind each soul does not explain the unity of consciousness, but only complicates the problem. This conception has been abandoned by modern psychology. It affords no help to the doctrine of immortality. For the hope of immortality is not grounded on the form of the soul, but upon its valuable content.

Traub's criticism of Pfleiderer is correct. It is probable that he has not correctly interpreted Pfleiderer, but it is certain that the latter did not do justice to Ritschl. When Ritschl rejects the soulin-itself, it is the scholastic entity that he has in mind. When Pfleiderer affirms the "in itself" of the soul, he does not mean it in the scholastic sense. Ritschl's position is here again a reflection of Lotze. ${ }^{44}$ Lotze rejects the scholastic conception of soul-substance. The relating activity of consciousness affirms its necessary unity. "It is not through a substance that things have being, but they have being when they are able to produce the appearance of a substance present in them." If Lotze used the term "substance" for the soul, he had in mind nothing more than the unity of consciousness. He considers that the idea of a substance as a sort of atom under each individual thing or soul is absurd. He chides Kant because, while he shows conclusively that the soul in the scholastic sense would be absolutely unknowable, he still seems to imply that, if we could only know it, we should have some very valuable knowledge. Lotze tells

43 Zeitschrift für Theologie und Kirche, I894, pp. 91-129.

44 Metaphysics, $\$ 243-47$. 
us that we know the being of the thing in what it is and does. "Every soul is what it shows itself to be-unity whose life is in definite ideas, feelings, and efforts." The idea of substance does not help us in our hope of immortality, but that hope rests upon the meaning of the universe and the significance of the soul in its relation to the whole.

We have seen that Ritschl accepts Lotze's ontology, which includes his doctrine of the soul. He is antagonistic to mysticism. He wishes to make a place for historical revelation and to put the proper value upon ethical action. Ritschl emphasizes a practical type of piety. The practical philosophy of Lotze appealed to him. They have much in common; but Ritschl lacks what Lotze possessedmoderation of statement and the power to recognize all phases of a truth, even the criticisms and views of his opponents. There is some truth in Garvey's statement. Consciousness is not exhausted in its conscious activities, and even so noted a psychologist as Professor James, who rejects the doctrine of soul-substance, and whose general psychological and philosophical position is more or less in line with Ritschlian thought, has nevertheless, in his Varieties of Religious Experiences, an appreciative chapter upon mysticism, and virtually finds place for revelation in the subliminal or subconscious self.

2. The Kantian theory of knowledge.-Pfleiderer asks: "If Ritschl agrees with Kant when he says the thing-in-itself is unknowable, how can he criticise him for limiting knowledge to phenomena ?"45 Flügel ${ }^{4}{ }^{6}$ finds in Ritschl a misinterpretation of Kant. Kant never says that real things are unknowable. Noumena, or things-inthemselves, are unknowable, but real things are phenomena, and these are what we know. Traub finds that Ritschl has accepted the common interpretation of Kant which, while it must be admitted that it has several passages in its favor, is nevertheless incorrect. Kant never meant to say that things-in-themselves are unknowable, but "that their interdependent changes ground the world of phenomena." Kant uses the thing-in-itself as a negative limiting concept (Grenzbegriff). It brings to expression the limits of our knowledge of experience, but it is not a positive reality which is at the basis of the phenomenal world and its changes. "Theoretical knowledge, in

45 Ritschl'sche Theologie, p. 2.

${ }_{46} \mathrm{~A}$. Ritschls philosophische und theologische Ansichten, p. 9. 
the sense of Kant, knows of no other reality than those of the world of phenomenon. Phenomenon and thing are one and the same; a being behind phenomenon is a mere chimera."

Pfleiderer's criticism is keen, but superficial. This might be said, in general, of his entire treatment of Ritschl. The very fact that Ritschl seems to contradict himself so squarely in two consecutive sentences ouglit to have led so able a critic as Pfleiderer to question his own interpretation. Pfleiderer says of a certain position of Ritschl: "That seems very simple and evident-so simple that one might only wonder that such sensible people as Plato and Kant could not have reached it." One feels like replying here to Pfleiderer: "This contradiction seems very evident and clear-so clear, in fact, that one can only wonder that so sensible a man as Ritschl might not even himself have noticed it." It is difficult for two men, representing such extremes in thought, spirit, and method, as Pfleiderer and Ritschl, to understand and appreciate each other. Pfleiderer's work, however, is not to be compared with that of Stählin. ${ }^{47}$ The extravagance of the criticism, and the whole tone and spirit of that work, must surely defeat the plain purpose of the author in the mind of any honest and thoughtful reader.

There is an apparent contradiction in Ritschl's statement, but his thought is consistent. We have pointed out that, if things-inthemselves are as the scholastics represent them, then they are unknowable. Ritschl says: "Kant affirms a true criticism of the scholastic interpretation of a thing." Ritschl criticises Kant because he saw this and still maintained their conception of a thing, and this compelled him to limit knowledge to phenomenon. "The latter part," says Ritschl, "is too near the scholastic theory to avoid its errors." Ritschl's position here is not difficult to understand, if one really wishes to understand him, nor is it inconsistent.

In regard to the criticisms of Flügel and Traub, the historical student of Kant must answer that there are two tendencies in Kant, and that Ritschl represents one and Traub the other. One line of Kant's thought does lead him to Traub's position. The real thing and phenomenon are one. The thing-in-itself is a limiting concept. It is a necessity of thought to complete experience. The more we 47 Kant, Lotze, und Ritschl. 
relate things, the better we know them. But, again, there is also the other line of thought in Kant, which Ritschl has correctly represented and justly criticised. Kant seems to have Locke's idea of the real essence of things, and to admit that thought cannot give us this. We do not know things-in-themselves, but that would be the most valuable knowledge, if we only could. For these things-in-tlemselves are the true realities, and, in contrast with them, the phenomena, which we know, are comparatively unreal. In the moral world we come in contact with these realities, but they lie behind the phenomena of sense as the cause of sensations. There is a realism in the system of Kant which is near the scholastic conception of a thing. Seth says ${ }^{48}$ that it never entered the mind of Kant to deny the existence of things in themselves. Paulsen 49 thinks "every unbiased reader must admit that Kant never for a moment doubted the existence of things-inthemselves. It was the primary and self-evident presupposition of his thought at all times." "The world of appearance implies as a necessary correlate a world that appears. Without this the idea of a phenomenal world would be meaningless." Professor Tufts ${ }^{\circ}$ shows how both these tendencies mentioned above are manifest in the thought of Kant as reflected in the Lose Blätter. The neoKantians have developed the idealistic tendency according to which the thing-in-itself is the ultimate category or notion by which we round off experience. Traub is a neo-Kantian, and naturally places this interpretation upon Kant. Of the two tendencies, that of Ritschl is probably truer to the thought of Kant himself. It is interesting also to notice that in his interpretation of Kant, Ritschl is in line with Lotze's ${ }^{51}$ interpretation and criticism of Kant.

3. The Lotzean theory of knowledge.-No other part of Ritschl's system has been subject to so severe criticism as the sections which contain his epistemological presuppositions. His interpreters differ very widely, but they nearly all unite in their condemnation of these presuppositions. Ritschl has been regarded as a subjective idealist,

48 "Epistemology in Locke and Kant and Epistemology of the Neo-Kantians," Philosophical Review, Vol. II, pp. 172-186. and 293-315.

49 Immanuel Kant, p. 154.

so Philosophical Review.

${ }^{51}$ Geschichte der Philosophie, §25; Outlines of Metaphysics, §4. 
as presenting subjective idealism and naïve realism combined, as a vulgar realist, as Kantian, and as a consistent follower of Lotze.

a) Subjective idealism.-This is the estimate of Stählin, Steinbeck, Rub, Wagener, and Luthardt. Stählin ${ }^{52}$ disputes Ritschl's claim to be Lotzean. For (I) Ritschl makes a distinction between actual things and things-in-themselves. (2) Lotze regards phenomenon as something which arises directly in the human mind and is purely subjective. Phenomena are the product of our minds in which things do not present themselves as they are, and by means of which no knowledge of actual things is given us. (3) Ritschl says that things-in-themselves are unknown, but Lotze does not regard them as absolutely unknowable. (4) Space with Lotze is a subjective intuition, and the thing which we cognize in the phenomenon given in space has as little objective reality as the spatial phenomenon in which it is cognized. "The thing has no objective reality." After pointing out these differences, Stählin proceeds to show the contradictions and inconsistencies in Ritschl's own position. Inasmuch as Steinbeck ${ }^{53}$ takes identically the position of Stählin, and seems to have followed him in his interpretation, we may sum up the position of these two critics as follows: (I) Ritschl contradicts himself in the terms "things-in-themselves" and "real things." They are not the same; for the former are unknowable, the latter are known. But they are the same; for Ritschl criticises Kant for denying knowledge of "real things," when he says that only "things-in-themselves" are unknowable. (2) Ritschl defines a thing as a purely formal concept without content. But the phenomena are real only as the thing appears in them. This leads us to pure subjectivity. (3) Or, phenomena are affections of sense. They are subjective states of the soul. But the soul is a thing, and the thing is a formal concept. We have states or qualities without subject or object. (4) The thing-in-itself is a memory-image. It has no objective reality, but the phenomena are appearances of the things-in-themselves; they therefore have no objective reality. They are shadows of shadows; they are appearances of memory-images. "Phenomenon has no

${ }^{2}$ Kant, Lotze, und Ritschl.

53 Das Verhältniss von Theologie und Erkenntniss-Theorie erörtert an den theologischen Erkenntniss-Theorien von A. Ritschl und A. Sabatier. 
existence; things given in perception as unities of phenomena have no existence. Things-in-themselves are empty shadows." Stählin draws the awful consequence. God and the soul go. And with it falls Ritschl's whole theology. Steinbeck thinks that Ritschl never meant to land in such subjectivity, and he finds several passages which show conclusively that Ritschl held firmly to the objective reality of God and things, but did so illogically. Pure subjectivity is the logical issue of Ritschl's principles.

Wagener ${ }^{54}$ and Rub ${ }^{55}$ find in Ritschl's statement of the genesis of the concept of a thing subjectivity of the Berkeleyan type. The phenomenal world is the real world. All things have their existence for the consciousness in which they are. The real thing is a formal concept. The thing-in-itself is a necessity of thought. This is not Kant's position, for he did not deny things-in-themselves. Ritschl teaches solipsism. In Ritschl's statement of the origin of the memoryimage Wagener finds his explanation of the origin of space. But the explanation is incorrect; for the first time we see a thing, we see it in space. For Ritschl the "projection of a thing-in-itself with constant marks is the same thing as to present an objective space in which things have place." The philosopher recognizes, according to Ritschl, that the thing in space arises only as an involuntary abstraction, as the projection of the memory-image. Time has its origin in the same manner. Wagener admits that, if Ritschl accepted Lotze's ontology, he could not be called a subjective idealist, and he quotes a passage from Ritschl ${ }^{5}$ which, he acknowledges, can be interpreted as showing that Ritschl had Lotze's conception of God. But the relation cannot be admitted, since in that case a Ritschlian theologian would need to be a Lotzean philospher, and, moreover, the position of Lotze leans toward the pantheism of Spinoza.

b) Subjective idealism and naive realism.-This is the position of Pfleiderer ${ }^{57}$ and Pfenningsdorf. ${ }^{8}$ In Ritschl's statement, "We know the thing in its appearances," Pfleiderer thinks the problem of knowledge is not even touched, much less solved. For phenomena are the

54 Jahrbücher für protestantische Theologie, 1884, pp. 194-227.

55 Die Erkenntnisstheorie von $R$. Lipsius verglichen mit denjenigen von Bredemann und Ritschl.

${ }^{6}$ Christliche Liebe, Vol. III, p. $20 x$.

57 See reference given.

$5^{8}$ Dogmatisches System von Lipsius und Ritschl. 
images of things presented by ourselves. They are within our consciousness. But the thing in itself cannot be this, for it must exist apart from any representation of it. Do, then, our images allow us to know the thing in itself accurately, or only inaccurately, or possibly not at all? Ritschl never answers. But in his little work Ritschl informs us that things in themselves are memory-images, and that real things are the products of our representing consciousness $(\$ 2$, p. $44 ; \S 4$, p. 64). Ritschl teaches us that the thing is a formal concept. Our faculty of presentation forms it through fastening sensations together, and we think it as being-for-itself, in analogy with our own souls; but there is nothing existing in itself which actually corresponds with this idea of ours. The thing is a formal concept "in which we express the continuity of our own subjective feeling of self." Ritschl teaches the doctrine of subjective idealism. And this doctrine fails to explain (a) the origin of sensation, $(b)$ why just these qualities and not others are united in the concept of a thing, $(c)$ why others experience the same unities as $\mathrm{I}$, and $(d)$ why I am justified in supposing that other persons beside myself exist at all. Subjective idealism always leads to realism, but seldom in so naïve a manner as in Ritschl. For in the same proposition in which he tells us that a thing is a product of the faculty of presentation, he makes the thing at the same time the cause of sensations. Here we have in one sentence subjective idealism and naĩve realism, with the contradiction that the thing is at the same time both cause and product.

Pfenningsdorf finds the same contradiction as Pfleiderer. The thing is both the product of the faculty of presentation and the cause of sensations, and no "unbiased reader" can deny the contradiction. Pfenningsdorf claims on the ground of Stählin, already given, that Ritschl is not Lotzean. Ritschl considers it vulgar and unphilosophic thinking to conclude from phenomena to things-in-themselves, but asserts that we know the thing in its appearance as the cause of its qualities. Here he would seem to assert existence apart from subjective phenomena as real being. But he passes over to define a thing as purpose and as a law of change. There is a manifest impossibility in considering the thing both cause and purpose; and the subjectivity of Ritschl is made manifest when the thing is defined as 
the law of its changing marks, since the thing is identified with the unity of its phenomena.

c) Nä̈ve realism.-Garvey, ${ }^{59}$ Ludemann, ${ }^{60}$ Wendland, ${ }^{6 \mathbf{I}}$ and Haug find in Ritschl a naïve realism. Garvey fails to find Lotze's ontology in Ritschl. Yet the latter does not pass into subjective idealism, as Stählin affirms, but into a vulgar realism. Ritschl is no philosopher, and is either "ignorant or indifferent to the problem of knowledge and existence." But Stählin is guilty of a misinterpretation of Ritschl, when he says that for him the thing is a purely formal concept. The temper of Stählin's book, the writer thinks, accounts for this, but he regrets that Professor Orr should lend "countenance to this misunderstanding." In addition to naïve realism, Garvey finds traces of Kant's phenomenalism in Ritschl.

Wendland claims that Ritschl held fast to an empiricism according to which in the immediate experience, and in it alone, we have the certainty of the reality of the object. The object is given immediately in perception, and there is no place for conceptual thinking.

Ludemann thinks Ritschl never meant to deny the existence of things. He affirms that things exist, and that we know them in themselves when we know them as they are for us. But, in opposition to the skepticism of the senses, Ritschl seems to think that reality is completely given in sensation and perception, and there is no place for thought in the construction of a thing. He has not learned the lesson of Kant's analytic. Ritschl assumes that we attain immediate knowledge of a thing. A knowledge of it in itself is given in our perceptions. He does not realize that there may be illusions and imperfections that must be eliminated by reflection. In this he cannot appeal to Lotze, for the latter never held that through senseperception one could attain the essence of a thing.

d) Kantianism.-Several of Ritschl's critics think that he has accepted the position of Kant. Kügelgen and Schöen ${ }^{62}$ say that he is nearer Kant than Lotze. Favre ${ }^{63}$ thinks Ritschl is like Kant in

59 Ritschlian Theology.

6o Protestantische Monatshefte, I897, pp. I89-205.

6r Albrecht Ritschl und seine Schüler.

${ }_{62}$ Origines historiques de la théologie de Ritschl.

${ }^{6} 3$ Les principes philosophiques de la théologie de Ritschl. 
that he limits knowledge to phenomena. Otto Ritschl ${ }^{64}$ says his father's position is virtually Kantian, and he agrees with Lotze only where the latter agrees with Kant. Orr ${ }^{65}$ finds the influence of Lotze over Ritschl to be marked, yet judges that his theory of knowledge is closer to that of Kant than to that of Lotze. Traub finds Ritschl's position to be the "geniune Kantian." For theoretical knowledge all reality is included in the world of phenomena, and it is the task of the categories to arrange the manifold of appearances in a unitary manner. Ritschl does not have, like Lotze, a world of metaphysical realities, but he is influenced by the latter in his conception of being. Ritschl has not sharply distinguished between the question of the genesis of a concept and that of its validity. When Pfleiderer, however, asks for the origin of sensations, he is asking for an explanation of consciousness. But this is an impossible demand. We cannot go behind consciousness. The category of causation cannot be carried beyond experience. The thing-in-itself behind phenomena is only a limiting concept. Our sole criterion of reality, in the theoretical reason, is whether or not a given concept can be articulated in the causal series. When one asks if this world of the theoretical reason has real existence, then one passes over from the standpoint of the pure reason to that of the practical reason. The feeling, willing self finds those things to have real existence which excite feelings of pleasure or pain, and which advanre or hinder the purposes of the will.

e) Lotzeanism.-Ritschl himself tells us that he accepts the Lotzean theory of knowledge, and expounds and defends it in his pamphlet. His statement is entitled to as much consideration as the judgment of any critic or disciple. His statement ought to be accepted until facts compel us to reject it. Ecke ${ }^{66}$ decides that Ritschl's position is that of Lotze. When Ritschl says that "one knows a thing first in its qualities, in its effects on our perceptions of another thing;" that "the marks are appearing effects of a cause;" that "the thing is cause in its effects;" that "sensations are caused by the thing;" that "there are causes which lead the soul and affect it as stimuli, etc.;" and when he chides Kant because he limits knowledge to phenomena, he can be understood only to affirm the 
existence and knowledge of real things. Ecke tells us that Thikötter conversed with Ritschl in regard to his theory of knowledge, and that Ritschl admitted his agreement with Lotze in ontology, and thought that by limiting his agreement to that section of his metaphysics he escaped the necessary consequences of Lotze's whole metaphysics. Swing ${ }^{67}$ finds Ritschl in agreement with Lotze, and he interprets the latter to affirm a knowledge of reality. Mielke ${ }^{68}$ passes the same judgment. Flügel ${ }^{69}$ finds in Ritschl's theology the dangerous pantheistic tendencies of Lotze's metaphysics. Ritschl's definition of a thing contains a nest of metaphysical inconsistencies. "Do things have a purpose in their effects ?" "How do we know a thing is cause of its marks? Do we know it, or infer it?" What is his meaning when he says the thing is the law of the change of its qualities? There is no real being, but we name the law of constant change, being. The thing as law of change cannot, then, be the cause of change. Ritschl has the monistic-pantheistic metaphysics of Lotze. For he says: "One must think the world as unity in order to explain the reciprocal action of things. But in this sense is the substance of the world more significant in the conception of a universal law than in that of cause?" Flügel regards this as in perfect harmony with the reasoning of Lotze by which the latter concludes to a unitary world-substance.

It is interesting to see the wide divergence of opinion among the critics of Ritschl. Some find the position which Ritschl takes in his larger work to contradict that in the smaller. Others find his teaching in both works to be consistent, but reject his position entirely. Some object to his solipsism, others fear his pantheism. His thing is a formal concept, and it is a naïve realism. He has no place for conceptual thought, and he is a genuine Kantian. Why all this difference of opinion? The standpoint of the individual critic answers in part. The speculative and pantheistic Pfleiderer misses that respect for the intellect that he desires. The Herbartian Flügel thinks that prominence is not given to the independent real; and the dogmatic theologian misses the element of supernaturalism;

${ }_{7}$ The Theology of Albrecht Ritschl.

68 Gottfried Mielke, Das System Albrecht Ritschl's dargestellt, nicht kritisirt.

69 See his A. Ritschl's philosophische und theologische Ansichten, pp. 9, 10. 
while the sympathetic Traub, both a Kantian and a Ritschlian, wishes his two masters to live in harmony. The standpoint of the man means more in a question of theology or philosophy than in one of mathematics or science. And the peculiar position of Ritschl to all other theological parties renders him susceptible to criticism from every-quarter.

But the theological and philosophical standpoints of the individual critics cannot entirely account for the wide difference of opinion. Ritschl's own statements are unclear and inexact. His Theologie und Metaphysik is a polemic, and was produced in the heat of controversy. It is an answer to objections, and is not meant to give an adequate treatment of epistemological problems. Statements are made which perhaps under other conditions would be modified or suffer a change of emphasis. Moreover, he means it, he tells us, to be an abbreviated statement of Lotze's general position, and he tacitly assumes that his opponents are familiar with the latter. There are certain passages in Ritschl which, if isolated, suggest every interpretation given. But when viewed in the light of the whole controversy, and with the background of the philosophic thought of his age, and especially that of Lotze, they can all be reconciled. His critics have made the mistake of criticising his position before they gave him sympathetic interpretation. His position may be untenable, but the first necessity, even to overthrow him, is a sympathetic interpretation. And this demands that one put himself in the position of the author, and view matters from his standpoint and in the light of his purpose. Ritschl's critics have failed to do this.

If we bring under consideration the criticisms of Ritschl which have just been presented, we have to deny the difference between Lotze and Ritschl that Pfenningsdorf and Stählin indicate. Ritschl does not differentiate things-in-themselves and real things. His position here is that of Lotze. There is an ambiguity in the term "thingsin-themselves." The scholastic "things-in-themselves" are not real things, but the precipitate of memory-images. But when things-inthemselves are correctly conceived, they are real things. Or, if one would make a difference at all, that difference would correspond to the difference between partial and perfect knowledge. Things-inthemselves are things in relation. We know them as they are related 
to us. A perfect knowledge would know all their relations. Again, it is incorrect to say that for Lotze phenomena give no knowledge of reality. There are passages in his system, and especially in his Logic, which would seem to lead to this conclusion; but his thought, taken as a whole, teaches that appearance is a knowledge of reality. Moreover, Lotze criticises Kant, because the latter teaches what is here imputed to him. When Stählin says that Lotze held that thingsin-themselves are not absolutely unknowable, he is correct; but this is precisely the position of Ritschl. Stählin's criticism shows that here he fails completely to understand Ritschl. For the whole point of the latter is an attack upon a "scholastic interpretation of a thing." Stählin is correct when he affirms that for Lotze space is a form of perception, and this is also Ritschl's position, and he reveals it clearly in his discussion of the personality of God. But when Stählin concludes that on that account the thing has no objective reality, he shows a lack of clear philosophic knowledge. What is meant by objectivity? Any presentation in consciousness has a certain objectivity; or objectivity may mean universality, or that which exists in space and time. Even for Kant objects have as much objective reality as the empirical self; for both are included in consciousness. For Lotze an objective reality has an existence for self. The thing has precisely the same "objective reality as the self." Neither is in space; but space is the form in which things appear to us, and this appearance conveys real information of the behavior of things. The same criticism may be urged against the term ausser uns as used by Steinbeck. Does it mean an object in space, or a Kantian thing-initself?

We have already pointed out that when Ritschl calls a "thing-initself" a memory-image, it is the scholastic conception of a thing that he has in mind. This failure of interpretation renders much of the. criticism against Ritschl absolutely worthless. Ritschl never says, as Pfenningsdorf claims, that it is a mistake of the vulgar to conclude from phenomena to things-in-themselves. The mistake of the vulgar is that they conclude to the scholastic thing-in-itself; to a substance behind and supporting qualities. Ritschl teaches us that, if we form a correct conception of the thing, we shall be led to Lotze's view, and affirms that the "cause is known in its effects." It is a 
pure piece of imagination on the part of Wagener, when he makes the memory-image Ritschl's explanation for the genesis of space and time. Ritschl tells us that he wishes to account for the scholastic view that we know things apart from their activity. So far as Ritschl reflects his psychological position, he is in harmony with Lotze, and no doubt would accept his explanation of the origin of space and time.

When Pfenningsdorf and Flügel criticise Ritschl's doctrine of the thing, they ought to interpret him in the light of the fuller exposition of Lotze. When one conceives cause as Lotze does, there is no contradiction in saying that the thing is both cause and purpose. For the self can be both cause and purpose. When we limit the term "law," as Lotze does, and keep in mind the methodological character of our concepts, the thing, when defined as law, is not reduced to a mere formal concept. Flügel as a realist raises the old question of the relation of the individual to the whole. Lotze denies mere becoming, with which Flügel charges him. Lotze denies the doctrine of independent reals, and it is his merit to have pointed out the insurmountable difficulties in this doctrine. But no one will claim that Lotze gave a final solution to the problem of individuality in its relation to the whole. When Flügel asks if the thing then is uncaused, he should remember that Lotze forbids us to ask after the cause of experience. Our task is not to create the world, but to understand it.

The criticism of Pfleiderer loses its force when we remember that Ritschl accepted Lotze's idea of the thing and of its relation to the self, and denied the position of Kant. If you define phenomena and conceive things-in-themselves as Kant did, then it is impossible to say that we know "the thing in its appearance." Even Ritschl might see that. But Lotze denies this position of Kant. Robins" says for Lotze this involves (I) a false and abstract distinction between form and matter; (2) the view that appearance only is known, at least directly; (3) the dogma that, if reality is knowable, it can be known only indirectly by the mediation of appearance which must be the identical copy or likeness of reality; (4) the traditional dualism which Kant accepted between subject and object. One might reject Lotze's position, but it is hardly fair to him to say that he has not

${ }^{70}$ See his Lotze's Theory of Knowledge, p. 34. 
"touched the problem of knowledge;" and if Ritschl indicates and accepts Lotze's position because he does not restate it in full, he ought not to be open to this charge. Neither should Garvey say that he is "no philosopher." Ritschl impresses the diligent student of his work with the fact that occasionally he did a bit of philosophic thinking.

A true interpretation of Ritschl shows the superficial and unfair nature of the criticisms of Stählin and Steinbeck. For the thing-initself is not a memory-image, but is a soul-like entity. A thing is not a phenomenon of consciousness. The concept of a thing in our consciousness is our knowledge of a thing. It is the nature of knowledge to be knowledge of something. While the concept of a thing is subjective, it gives us information of a transubjective reality. Knowledge is a product of experience, but it conveys information of things which are causes of experience. The thing is not both cause and product of experience, as Pfleiderer affirms, but the thing is the cause of the concept of a thing, which is a product of the experience of the self. Ritschl never defines a thing as a purely formal concept. That, as Garvey correctly points out, is just his criticism of Frank's imperfect concept of a thing.

If the position of Ritschl is that of Lotze, he can scarcely be charged with naïve realism. He agrees with Lotze that the individual alone is real, but it is by reflection that he passes on from the elementary to the consistent concept of a thing. There are isolated passages where he tells us that sensation is our only warrant for affirming that things exist, and Lotze says the same. The common man does seek to exclude errors by repeated observation and by comparing his conceptions with others. This is, in fact, the scientific method of observation and experiment, and involves reflection, and is the basis of further reflection. Ritschl does not exclude conceptual thinking. $\mathrm{He}$ is not a Hegelian, but is by no means a mere empiricist.

Our aim has been to interpret Ritschl, and it is not our task to give a full and critical appreciation of his position. Criticism might better be directed to the fuller and clearer statement of Lotze; for it is only in the light of the garment of Lotze that the shreds and patches of Ritschl can be put together. The philosophic thought of today is scarcely able to accept this doctrine of ontology. Schiller's criti- 
$\operatorname{cism}^{71}$ seems to the writer to be just. To accept the world as given, and to recognize that we cannot go behind experience, is to accept the world in which things are in interaction. Lotze's concept of the absolute does not explain change. We do not know why there should be change in the absolute. If the interaction of things necessitates a change in the absolute to restore equilibrium, there seems to be no place for freedom. When Lotze assumes freedom, he does it at the expense of the absolute.

From the standpoint of modern psychology and logic, Lotze's position may be criticised. Jones ${ }^{72}$ has done this in his philosophy of Lotze. What is the relation between sensation and conception? At one time all is given in sensation, and thought has merely to do over the work of sensation. At another time thought has a bare multiplicity given, and it must combine the elements. Lotze has a "psychic mechanism," which takes the place of Kant's "imagination," and mediates between sense and understanding. In places, at least, he implies that a datum is given, and that we can have a subjective consciousness before we have an objective consciousness, so that thought has "to objectify the subjective." Ritschl seems to show, in his brief statement, the same mistake. As a psychological analysis his formation of a concept is not correct. He seems to assume that sensations are given. But sensations are an abstraction. They are an abstraction of the psychologist just as atoms are of the physicist. It is an undifferentiated experience which is immediately given, and from which, for logical purposes, both universals and particulars are abstracted. We must remember, of course, the methodological character of Lotze's concepts. It is probably true that Lotze held that there was a cognitive element in every sensation, and it is in this light that we have interpreted him.

From the epistemological point of view, it is difficult to see how an idea is not a copy of reality, and yet is valid of, and gives information concerning, reality. ${ }^{73}$ Lotze can hardly escape the copy-theory which he rejects. We are certain, by immediate intuition or by

${ }_{71}$ "Lotze's Monism," Philosophical Review, Vol. pp. 225-45.

72 Henry Jones, The Philosophy of Lotze's Doctrine of Thought; see also trenchant criticism by Dewey, in Studies in Logical Theory.

73 See John Dewey, Studies in Logical Theory, pp. $54 \mathrm{ff}$. 
direct sensation, that we have a knowledge of reality. If this is true, there does not seem to be much room for thought. ${ }^{74}$

Things are made of such stuff as thoughts are. They are thoughtzonstructs and represent modes of action. Thought itself arises in experience when a habit is broken, to form a new method or habit of action. From the intellectual point of view, the thing is a concept; from the practical, it is a more or less fixed mode of action. Traub is correct when he says that the reality of a thing is determined by our feeling-willing nature; but he fails to realize that thought in the service of the will forms the concept as a means of action. There is but one test to the reality of a thing, and that test is its function.

74 See discussions on epistemology in the Philosophical Review, by Seth, Rogers, Tufts, and MacLennan. 


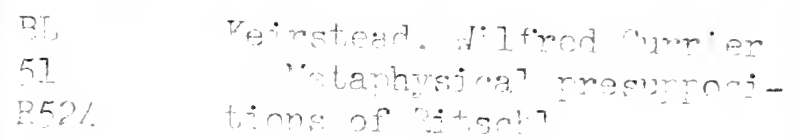

PLEASE DO NOT REMOVE CARDS OR SLIPS FROM THIS POCKET UNIVERSITY OF TORONTO LIBRARY 
